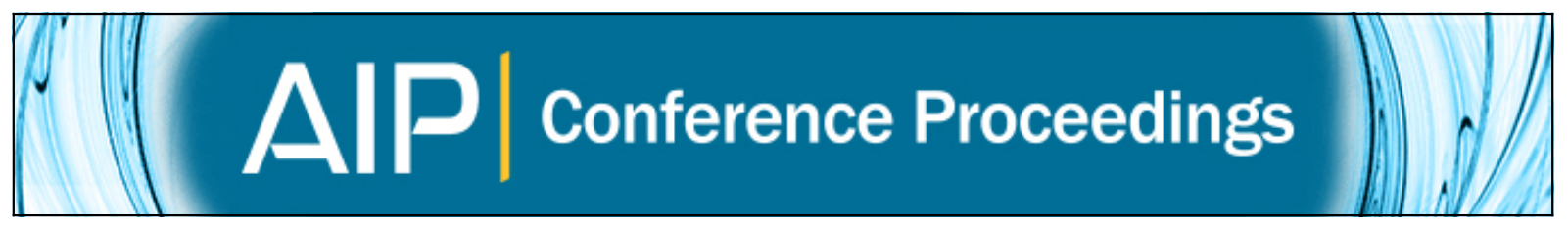

\title{
Optical properties of borotellurite glasses containing metal oxides
}

Nirmal Kaur, Atul Khanna, P. S. R. Krishna, and Fernando González

Citation: AIP Conference Proceedings 1665, 070029 (2015); doi: 10.1063/1.4917893

View online: http://dx.doi.org/10.1063/1.4917893

View Table of Contents: http://scitation.aip.org/content/aip/proceeding/aipcp/1665?ver=pdfcov

Published by the AIP Publishing

\section{Articles you may be interested in}

Spectroscopic properties of Er3+/Yb3 + Co-doped zinc boro-tellurite glasses for $1.5 \mu \mathrm{m}$ broadband optical amplifiers

AIP Conf. Proc. 1665, 070007 (2015); 10.1063/1.4917871

Optical studies on Eu3+ doped boro-tellurite glasses

AIP Conf. Proc. 1447, 549 (2012); 10.1063/1.4710121

Er $3+$-doped boro-tellurite glass for optical amplification in the $1530-1580 \mathrm{~nm}$

J. Appl. Phys. 103, 083543 (2008); 10.1063/1.2908873

Raman characteristics and nonlinear optical properties of tellurite and phosphotellurite glasses containing heavy metal oxides with ultrabroad Raman bands

J. Appl. Phys. 100, 023107 (2006); 10.1063/1.2215218

Optical properties of glasses containing copper oxide particles

Appl. Phys. Lett. 68, 584 (1996); 10.1063/1.116506 


\title{
Optical Properties of Borotellurite Glasses Containing Metal Oxides
}

\author{
Nirmal Kaur ${ }^{1}$, Atul Khanna ${ }^{1 *}$, P. S. R. Krishna ${ }^{2}$ and Fernando González ${ }^{3}$ \\ ${ }^{I}$ Glass Physics and Sensors Laboratory, Department of Physics, \\ Guru Nanak Dev University, Amritsar-143005, Punjab, India \\ ${ }^{2}$ Solid State Physics Division, Bhabha Atomic Research Centre, Mumbai-400085, India \\ ${ }^{3}$ Department of Chemistry and Process \& Recourse Engineering, \\ University of Cantabria, Santander-39005, Spain \\ *E-mail:atul.phy@gndu.ac.in
}

\begin{abstract}
Glass samples of the system: $5 \mathrm{M}_{\mathrm{x}} \mathrm{O}_{\mathrm{y}}-20 \mathrm{~B}_{2} \mathrm{O}_{3}-75 \mathrm{TeO}_{2}: \mathrm{M}_{\mathrm{x}} \mathrm{O}_{\mathrm{y}}=\mathrm{WO}_{3}, \mathrm{Nb}_{2} \mathrm{O}_{5}, \mathrm{PbO}, \mathrm{Nd}_{2} \mathrm{O}_{3}, \mathrm{Y}_{2} \mathrm{O}_{3}, \mathrm{Eu}_{2} \mathrm{O}_{3}$ were prepared by melt quenching and characterized by X-ray diffraction, density, Differential Scanning Calorimetry, UVvisible and FTIR spectroscopy. XRD patterns confirmed the amorphous structure of all samples. Glass transition temperature was maximum in borotellurite glass containing $\mathrm{Y}_{2} \mathrm{O}_{3}$. Refractive index, atomic polarizability and basicity increased in the following order of ions: $\mathrm{Y}^{3+}<\mathrm{Eu}^{3+}<\mathrm{Pb}^{2+}<\mathrm{Nd}^{3+}<\mathrm{Nb}^{3+}<\mathrm{W}^{6+}$. FTIR studies showed that $\mathrm{PbO}$ is outstanding in enhancing the concentration of tetrahedral borons in the borotellurite network.
\end{abstract}

Keywords: Borotellurite glasses, XRD, DSC, FTIR and UV-Visible spectroscopy.

PACS: 81.05.Kf, 61.05.cp, 65.60.+a, 63.50.- $\mathrm{x}$ and 78.40.-q

\section{INTRODUCTION}

Tellurite glasses have a wide range of applications. One of the commercial applications of tellurite glasses is in the field of optical communication due to their outstanding properties like high refractive index, high optical non-linearity and good infrared transmittance [1-5]. Tellurite glasses have been reported to exhibit 30 times higher Raman gain coefficients than silica glass and find application in Raman amplifiers and non-linear optical waveguides [6, 7]. Many studies are reported on the technological importance of tellurite glasses containing transitional metal and/or rare earth ions in memory switching devices and as cathode materials for batteries [8].

In this work, we report the study of short-range structure and optical and thermal properties of borotellurite glasses doped with $\mathrm{W}^{6+}, \mathrm{Nb}^{3+}, \mathrm{Pb}^{2+}, \mathrm{Nd}^{3+}$, $\mathrm{Y}^{3+}$ and $\mathrm{Eu}^{3+}$. Glasses were characterized by density, X-ray diffraction (XRD), Differential Scanning Calorimetery (DSC) and UV-visible and FTIR spectroscopy.

\section{EXPERIMENTAL METHODS}

Glasses of the system: $5 \mathrm{M}_{\mathrm{x}} \mathrm{O}_{\mathrm{y}}-20 \mathrm{~B}_{2} \mathrm{O}_{3}-75 \mathrm{TeO}_{2}$ : $\mathrm{M}_{\mathrm{x}} \mathrm{O}_{\mathrm{y}}=\mathrm{WO}_{3}, \mathrm{Nb}_{2} \mathrm{O}_{5}, \mathrm{PbO}, \mathrm{Nd}_{2} \mathrm{O}_{3}, \mathrm{Y}_{2} \mathrm{O}_{3}, \mathrm{Eu}_{2} \mathrm{O}_{3}$ were prepared using $\mathrm{H}_{3} \mathrm{BO}_{3}$ (Sigma Aldrich Inc., USA, 99.5\%), $\mathrm{TeO}_{2}$ (Sigma Aldrich Inc., USA, 99\%), and $\mathrm{WO}_{3}, \mathrm{Nb}_{2} \mathrm{O}_{5}, \mathrm{PbO}, \mathrm{Nd}_{2} \mathrm{O}_{3}, \mathrm{Y}_{2} \mathrm{O}_{3}$ and $\mathrm{Eu}_{2} \mathrm{O}_{3}$ as starting materials. The chemicals in the above mentioned compositions were weighed and sintered at $300^{\circ} \mathrm{C}$ for $24 \mathrm{~h}$ and then melted in a temperature range of $800^{\circ} \mathrm{C}$ to $900^{\circ} \mathrm{C}$ in a platinum crucible. Glass samples were prepared by normal quenching technique in which a small amount of melt was quenched on a brass block and a button shaped sample was obtained and immediately transferred to a furnace kept at a temperature of about $80^{\circ} \mathrm{C}$ lower than the glass transition temperature. Samples were annealed for 30 min and then slowly cooled to room temperature.

\section{RESULTS AND DISCUSSION}

$\mathrm{X}$-ray diffraction measurements were performed on Bruker D8 Focus X-ray diffractometer with $\mathrm{Cu} \mathrm{K}_{\alpha}$ radiation $(\lambda=1.54056 \AA)$ in the $2 \theta$ range of $10^{\circ}-70^{\circ}$. Figure 1 shows the XRD patterns of borotellurite 
glasses doped with metal oxides. These patterns do not show any sharp peaks, but the characteristic broad humps due to short-range order in glasses.

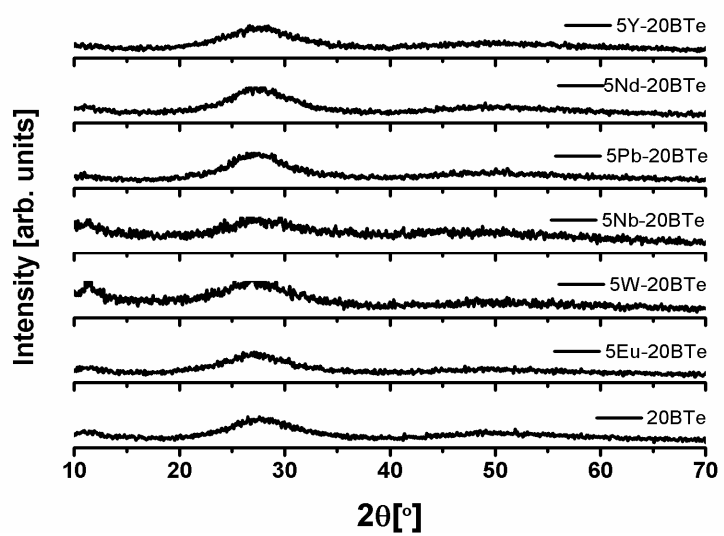

FIGURE 1. XRD patterns of borotellurite glasses doped with different metal oxides. calculated by dividing the absorbance A, with sample thickness and is plotted in figure 3 .

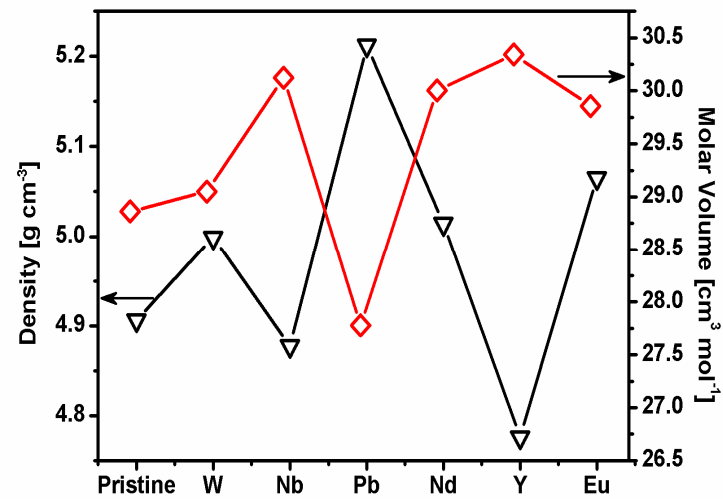

FIGURE 2. Density and molar volume variation in borotellurite glasses containing metal oxides.

TABLE 1. Molecular weight, density, molar volume and glass transition temperature of borotellurite glasses doped with metal oxides.

\begin{tabular}{|c|c|c|c|c|c|}
\hline Sample Code & Composition & $\begin{array}{c}\text { Molecular } \\
\text { Weight } \\
{\left[\mathrm{g} \mathrm{mol}^{-1}\right]}\end{array}$ & $\begin{array}{l}\text { Density } \\
{\left[\mathrm{g} \mathrm{cm}^{-3}\right]}\end{array}$ & $\begin{array}{c}\text { Molar Volume } \\
{\left[\mathrm{cm}^{3} \mathbf{~ m o l}^{-1}\right]}\end{array}$ & $\begin{array}{c}\mathbf{T}_{\mathbf{g}} \\
{\left[{ }^{\circ} \mathbf{C}\right]}\end{array}$ \\
\hline 20BTe & $0.20 \mathrm{~B}_{2} \mathrm{O}_{3}-0.80 \mathrm{TeO}_{2}$ & 141.61 & 4.906 & 28.86 & 352 \\
\hline $5 \mathrm{~W}-20 \mathrm{BTe}$ & $0.05 \mathrm{WO}_{3}-0.20 \mathrm{~B}_{2} \mathrm{O}_{3}-0.75 \mathrm{TeO}_{2}$ & 145.21 & 4.999 & 29.05 & 358 \\
\hline $5 \mathrm{Nb}-20 \mathrm{BTe}$ & $0.05 \mathrm{Nb}_{2} \mathrm{O}_{5}-0.20 \mathrm{~B}_{2} \mathrm{O}_{3}-0.75 \mathrm{TeO}_{2}$ & 146.92 & 4.877 & 30.12 & 369 \\
\hline $5 \mathrm{~Pb}-20 \mathrm{BTe}$ & $0.05 \mathrm{PbO}-0.20 \mathrm{~B}_{2} \mathrm{O}_{3}-0.75 \mathrm{TeO}_{2}$ & 144.78 & 5.212 & 27.78 & 340 \\
\hline $5 \mathrm{Nd}-20 \mathrm{BTe}$ & $0.05 \mathrm{Nd}_{2} \mathrm{O}_{3}-0.20 \mathrm{~B}_{2} \mathrm{O}_{3}-0.75 \mathrm{TeO}_{2}$ & 150.45 & 5.014 & 30.00 & 385 \\
\hline $5 Y-20 B T e$ & $0.05 \mathrm{Y}_{2} \mathrm{O}_{3}-0.20 \mathrm{~B}_{2} \mathrm{O}_{3}-0.75 \mathrm{TeO}_{2}$ & 144.91 & 4.776 & 30.34 & 393 \\
\hline $5 \mathrm{Eu}-20 \mathrm{BTe}$ & $0.05 \mathrm{Eu}_{2} \mathrm{O}_{3}-0.20 \mathrm{~B}_{2} \mathrm{O}_{3}-0.75 \mathrm{TeO}_{2}$ & 151.22 & 5.065 & 29.86 & 388 \\
\hline
\end{tabular}

Density of glasses were measured by Archimedes principle using an electronic balance with an accuracy of $10^{-4} \mathrm{~g}$. Turpentine oil was used as an immersion liquid. Density and molar volume values are given in Table 1. Density increases on adding metal oxides in the glass network and is maximum for glass containing $\mathrm{PbO}$ [Figure 2].

Thermal studies were performed on SETARAM SETSYS Evolution-1750 system in the temperature range of $200-850^{\circ} \mathrm{C}$ at a heating rate of $10^{\circ} \mathrm{C} / \mathrm{min}$, in air flow rate of $20 \mathrm{ml} / \mathrm{min}$ in Pt pans. From DSC scans, glass transition temperature, $\mathrm{T}_{\mathrm{g}}$ was determined [Table 1]. $T_{g}$ is maximum for the sample having $5-\mathrm{mol} \%$ of $\mathrm{Y}_{2} \mathrm{O}_{3}$ and minimum for glass containing $\mathrm{Pb}^{2+}$ ion. All metal ions except $\mathrm{Pb}^{2+}$ strengthened the binary borotellurite glass network due to the incorporation of metal oxide bonds with higher bond enthalpies.

Optical absorption spectra of polished disk shaped borotellurite glasses were measured at room temperature on Shimadzu 1601 double beam UVvisible spectrophotometer in wavelength range of 200$1100 \mathrm{~nm}$. The optical absorption coefficient $\alpha(\lambda)$ was

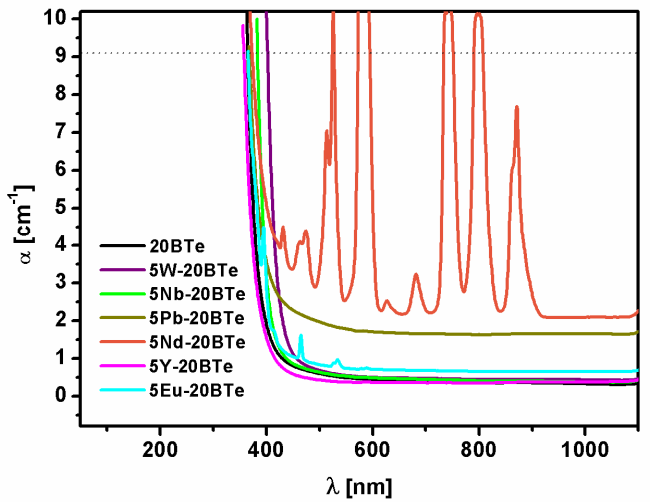

FIGURE 3. Absorption spectra ( $\alpha$ vs $\lambda$ ) of borotellurite glasses.

From $\alpha$ vs $\lambda$ plots, absorption edge, $\lambda_{\mathrm{o}}$ was determined as the wavelength at which $\alpha=9 \mathrm{~cm}^{-1}$ [Table 2]. The absorption edge shifted towards longer wavelengths on adding metal oxides. Optical band gap, $\mathrm{E}_{\mathrm{g}}$ of glasses was determined from $\lambda_{\mathrm{o}}$. $\mathrm{E}_{\mathrm{g}}$ was used to calculate the optical electronegativity $\chi$, refractive index $n$, 
electronic polarizability $\alpha_{0}$ and optical basicity $\Lambda$, of glasses using the formulae reported in the literature [9]. The calculated values are given in table 2 . that $\mathrm{N}_{4}$ is nearly the same for the undoped borotellurite sample: 20BTe and the glasses doped with $\mathrm{Nd}^{3+}$ and $\mathrm{Nb}^{3+}$. Maximum $\mathrm{N}_{4}$ is in the sample containing $\mathrm{Pb}^{2+}$ and the minimum is observed in the glass with $\mathrm{W}^{6+}$.

TABLE 2. Optical energy gap and $\mathrm{N}_{4}$ in borotellurite glasses containing metal ions.

\begin{tabular}{cccccccc}
\hline $\begin{array}{c}\text { Sample } \\
\text { Code }\end{array}$ & $\begin{array}{c}\text { Absorption edge } \\
\boldsymbol{\lambda}_{\mathbf{0}},[\mathbf{n m}]\end{array}$ & $\begin{array}{c}\text { Energy gap } \\
\mathbf{E}_{\mathbf{0}}[\mathbf{e V}]\end{array}$ & $\boldsymbol{\chi}$ & $\mathbf{n}$ & $\boldsymbol{\alpha}_{\mathbf{o}}$ & $\boldsymbol{\Lambda}$ & $\mathbf{N}_{\mathbf{4}}$ \\
\hline 20BTe & 365 & 3.4 & 0.915 & 2.28 & 2.68 & 1.24 & 0.27 \\
5W-20BTe & 402 & 3.1 & 0.831 & 2.35 & 2.75 & 1.28 & 0.17 \\
5Nb-20BTe & 383 & 3.3 & 0.872 & 2.32 & 2.71 & 1.26 & 0.27 \\
5Pb-20BTe & 368 & 3.4 & 0.908 & 2.29 & 2.68 & 1.25 & 0.38 \\
5Nd-20BTe & 373 & 3.3 & 0.896 & 2.30 & 2.69 & 1.25 & 0.27 \\
5Y-20BTe & 357 & 3.5 & 0.936 & 2.27 & 2.66 & 1.23 & 0.21 \\
5Eu-20BTe & 366 & 3.4 & 0.913 & 2.28 & 2.68 & 1.24 & 0.24 \\
\hline
\end{tabular}

Optical energy gap of glasses containing metal ions was lower than undoped borotellurite glass (i.e. sample 20BTe) except for the sample containing $\mathrm{Y}^{3+}$. The optical electronegativity was lowest for glass having $\mathrm{W}^{6+}$. Values of refractive indices follow the trend: $5 \mathrm{Y}-$ 20BTe $<20 \mathrm{BTe}<5 \mathrm{Eu}-20 \mathrm{BTe}<5 \mathrm{~Pb}-20 \mathrm{BTe}<5 \mathrm{Nd}-$ 20BTe $<5 \mathrm{Nb}-20 \mathrm{BTe}<5 \mathrm{~W}-20 \mathrm{BTe}$.

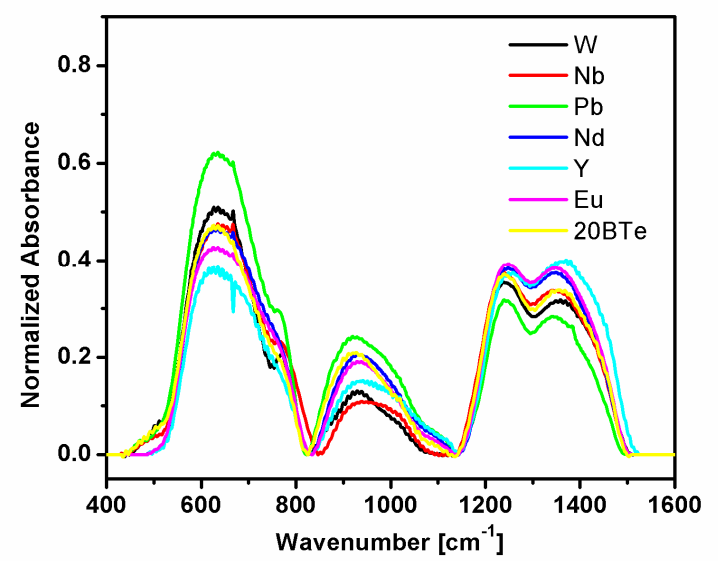

FIGURE 4. FTIR absorption spectra of borotellurite glasses doped with metal ions.

The FTIR absorption spectra show three bands in the wavenumber ranges of $500-800 \mathrm{~cm}^{-1}, 800-1150$ $\mathrm{cm}^{-1}$ and $1150-1550 \mathrm{~cm}^{-1}$ [Figure 4]. The first band in the wavenumber range of $500-800 \mathrm{~cm}^{-1}$ is due to Te-O vibrations in different Te-O units. The bands in the wavenumber ranges of $820-1140 \mathrm{~cm}^{-1}$ and $1150-1550$ $\mathrm{cm}^{-1}$ are due to $\mathrm{B}-\mathrm{O}$ stretching vibrations in $\mathrm{BO}_{4}$ and $\mathrm{BO}_{3}$ units respectively [4]. Areas under the second and third bands i.e. $\mathrm{A}_{4}$ and $\mathrm{A}_{3}$ are calculated and the ratios of these areas $A_{4} /\left(A_{4}+A_{3}\right)$ is considered proportional to the fraction of tetrahedral borons $\left(\mathrm{N}_{4}\right)$ in the glass network. It is clear from the data presented in table 2

\section{CONCLUSIONS}

Borotellurite glasses were prepared with 5-mol\% of $\mathrm{W}^{6+}, \mathrm{Nb}^{3+}, \mathrm{Pb}^{2+}, \mathrm{Nd}^{3+}, \mathrm{Eu}^{3+}, \mathrm{Y}^{3+}$ and their properties were compared with undoped borotellurite glass. Glass transition temperature is maximum for 5Y-20BTe sample. Refractive index, atomic polarizability and basicity increases in the following order of dopant ions: $\mathrm{Y}^{3+}<20 \mathrm{BTe}<\mathrm{Eu}^{3+}<\mathrm{Pb}^{2+}<\mathrm{Nd}^{3+}<\mathrm{Nb}^{3+}<\mathrm{W}^{6+}$. Conversely optical energy gap is lowest for glass containing $\mathrm{WO}_{3}$ and is highest for the glass with $\mathrm{Y}_{2} \mathrm{O}_{3}$. Also, $\mathrm{PbO}$ produces a maximum increase in $\mathrm{N}_{4}$ while $\mathrm{WO}_{3}$ suppresses it.

\section{REFERENCES}

1. H. Nasu, O. Matsushita, K. Kamiya, H. Kobayashi and K.i. Kubodera, Journal of Non-Crystalline Solids 124, 275-277 (1990).

2. M.H. Bhat, M. Kandavel, M. Ganguli and K.J. Rao, Bulletin of Materials Science 27, 189-198 (2004).

3. K.J. Rao and M. Harish Bhat, Physics and Chemistry of Glasses 42, 255-264 (2001).

4. P. Gayathri Pavani, K. Sadhana and V. Chandra Mouli, Physica B: Condensed Matter 406, 1242-1247 (2011).

5. P. Gayathri Pavani, S. Suresh and V. Chandra Mouli, Optical Materials 34, 215-220 (2011).

6. G.S. Murugan, T. Suzuki and Y. Ohishi, Journal of Applied Physics 100, 023107 (2006).

7. R. Stegeman, L. Jankovic, H. Kim, C. Rivero, G. Stegeman, K. Richardson, P. Delfyett, Y. Guo, A. Schulte and T. Cardinal, Optics Letters 28, 1126-1128 (2003).

8. K.A. Aly, Y.B. Saddeek and A. Dahshan, Philosophical Magazine 90, 4429-4441 (2010).

9. X. Zhao, X. Wang, H. Lin and Z. Wang, Physica B: Condensed Matter 403, 2450-2460 (2008). 